\title{
The Synagogue In Late Antiquity
}

\section{Lee I Levine Jewish Theological Seminary of America}

Palestine in Late Antiquity - Google Books Result The Synagogue in late antiquity edited by Lee I. Levine. Papers from a conference sponsored by the Center for Synagogue Studies, the Jewish Theological THE SYNAGOGUE IN LATE ANTIQUITY. A Centennial - JStor Ancient synagogues in Palestine - Wikipedia, the free encyclopedia Visual Judaism in Late Antiquity - Levine, Lee I. - Yale University Press Evolution of the Synagogue: Problems and Progress - Google Books Result The Synagogue in Late Antiquity: Lee I. Levine: 9780897575096 After the destruction of the Temple in Jerusalem, the local synagogue became its substitute and from Late Antiquity onward, the number of synagogues. The Synagogue in late antiquity - HathiTrust Digital Library A new type of Jewish art emerged in Late Antiquity, when artists produced visual. what forms of artistic expression would be displayed in their synagogues. This study is a re-assessment of the impact of Christian art and architecture on synagogues in Late Antique Palestine, focussing on features common to both. Ancient Synagogues - Archaeology and Art: New Discoveries and. - Google Books Result Feb 6, 2015. Visual Judaism in Late Antiquity: Historical Contexts of Jewish Art the zodiacHelios motifs portrayed in Palestinian synagogue floor mosaics. The Image and Its Prohibition in Jewish Antiquity - CAA Reviews The Synagogue in Late Antiquity. Front Cover. Lee I. Levine. American Schools of Oriental Research, 1987 - Jewish art and symbolism - 218 pages. Astrology and Judaism in Late Antiquity Astrology in Synagogue Art List of Publications - The Hebrew University of Jerusalem Pagans and Christians in Late Antiquity: A Sourcebook - Google Books Result Annotation The synagogue was one of the most central and revolutionary institutions of. of the synagogue from the Hellenistic period to the end of late antiquity. Jewish Art in Late Antiquity and Early Byzantium. In early Byzantine synagogues, specifically Jewish symbols—shofarot ram's horns, menorot branched Synagogue in Late Antiquity: Lee I. Levine: 9780897575096 Review of Lee I. Levine, Visual Judaism in Late Antiquity: Historical Contexts of Zodiac," "Religious Components of Jewish Art and Synagogue Sanctity," and Visual Judaism in Late Antiquity - Biblical Archaeology Society The Synagogue in Late Antiquity by Lee I. Levine, 9780897575096, available at Book Depository with free delivery worldwide. ?Table of Contents: The Synagogue in late antiquity Full Title: The Synagogue in late antiquity ed. by Lee I. Levine. Corporate Author: Jewish Theological Seminary of America. Center for Synagogue Studies. The Ancient Synagogue: The First Thousand Years - Lee I. Levine Hebrew Studies 29 1988. 167. Reviews. THE SYNAGOGUE. IN LATE ANTIQUITY. Lee I. Levine, ed. A. Centennial Publication of The Jewish. Theological. Jewish Art in Late Antiquity and Early Byzantium Thematic Essay. I. Levine, The Sages and the Synagogue in Late Antiquity: The Evidence of the. Galilee. Gary A. Rendsbug, The Galilean Background of Mishnaic Hebrew Jewish and Other Imperial Cultures in Late Antiquity: Literary, Social. Judaism in Late Antiquity: The Special Problem of the Synagogue - Google Books Result ? Religious Diversity in Late Antiquity - Google Books Result Synagogue in Late Antiquity Lee I. Levine on Amazon.com. *FREE* shipping on qualifying offers. Ancient Synagogues: Historical Analysis and Archaeological Discovery - Google Books Result If Late Antiquity, the rabbinic era, is indeed Judaism's formative period, then a full. the Roman Empire and filled the benches of non-rabbinic synagogues. Review of Lee I. Levine, Visual Judaism in Late Antiquity: Historical Lee I. Levine, ed. The Galilee in Late Antiquity. New York: Jewish Nov 7, 2014. From the remarkable wall paintings of the Dura Europos synagogue to the. The pagan motifs in Late Antique Jewish art must have been Tagging sacred space in the Dura-Europos synagogue Journal of. Late Antiquity: A Guide to the Postclassical World - Google Books Result Jun 17, 2014. Z. Weiss, The Sepphoris Synagogue: Deciphering an Ancient Message: in Z. Weiss, Public Spectacles in Roman and Late Antique Palestine The Synagogue in Late Antiquity - Google Books H iya", into a doorpost of the synagogue in Roman Dura-Europos. ulations of late antiquity, the Dura synagogue continues to loom large in the historical. Alexandria in Late Antiquity: Topography and Social Conflict - Google Books Result Jews and Christians in Late Antiquity: An Interdisciplinary Research. Astrology and Judaism in Late Antiquity. Chapter Five Astrology In Synagogue Art. In this fifth and final chapter, we will discuss the synagogue zodiac mosaics Art and Architecture of the Synagogue in Late Antique Palestine Brill Judaism in late antiquity - Google Books Result Jews and Christians in Late Antiquity: An Interdisciplinary Research Initiative. the Mediterranean, originating primarily from within the urban synagogues of the 